\title{
REVISION ACETABULAR CUP REPLACEMENT WITH BURCH-SCHNEIDER CAGE: OUR EXPERIENCE
}

Ananthula Krishna Reddy ${ }^{1}$, C. Kama Raj ${ }^{2}$, Ashok Ohatker ${ }^{3}$, Prashanth Velugu ${ }^{4}$, B. Srinivas ${ }^{5}$

\section{HOW TO CITE THIS ARTICLE:}

Ananthula Krishna Reddy, C. Kama Raj, Ashok Ohatker, Prashanth Velugu, B. Srinivas. "Revision Acetabular Cup Replacement with Burch-Schneider Cage: Our experience". Journal of Evolution of Medical and Dental Sciences 2015; Vol. 4, Issue 71, September 03; Page: 12460-12462, DOI: 10.14260/jemds/2015/1793

ABSTRACT: A young male patient, who met with a Road traffic accident, sustained right acetabular fracture, which was fixed with recon plate. Subsequently right hip joint was ended in severe secondary osteoarthritis with avascular necrosis. For that total hip replacement was done, which was failed with in few months with proximal migration of acetabular cup. CT scan revealed a large deficit in the roof and posterior wall of the acetabulam, which could not be managed by simple bone graft. A revision acetabular cup replacement was performed by reconstructing and reinforcing cup with the help of BURCH-SCHNEIDER CAGE, which provides a stable metal back up for the prosthetic cup in the presence of large acetabular defects.

KEYWORDS: Acetabular defect, Revision cup Replacement, Anti-protrusio Cage.

INTRODUCTION: A 31 year old male patient, who met with a Road traffic accident, sustained Right acetabular fracture, and fracture shaft of left femur which were fixed with recon plate, and an interlocking nail respectively. One year after surgery he presented with avascular necrosis of Right femoral head, and subsequent osteoarthritis of right hip joint.

For that total hip replacement was done, but it was failed with in few months. There was proximal migration of acetabular cup. CT scan revealed a large deficit in the roof, anterior wall and posterior wall of the acetabulam, (Fitting into Type 3A Paprosky acetabular defect. ${ }^{1}$ ), which could not be managed by simple bone graft.

Hence planned to go for revision acetabular cup replacement by reconstructing and reinforcing cup with the help of anti-protrusio cage (BURCH-SCHNEIDER CAGE), which provides a stable metal back up. ${ }^{2}$ for the prosthetic cup in the presence of large acetabular defects.

Operative Technique: Through the previous postero lateral operative scar, the hip joint was opened. Without disturbing the femoral component, only the failed acetabular component was removed. A through debridement was done. The defect in the roof and adjacent walls was assessed. The muscle over the iliac bone was cleared to enable the cage to seat on it. A slot was cut into the ischium.

The inferior flange of the BURCH-SCHNEIDER CAGE is first driven into ischial slot. Then the superior flange was fixed on to the iliac bone with titanium screws. After placing the cage the defective gaps were packed with bone graft. Then a $48 \mathrm{~mm}$ diameter polyethylene cup was cemented into the cage. With a new $32 \mathrm{~mm}$ head component the joint was reduced.

Post Operatively: For the initial six weeks the patient was allowed only partial weight-bearing. Gradually full weight-bearing was allowed thereafter.

RESULTS: No pain while walking. ROM: $0-100^{\circ}$ of flexion, $10^{\circ}$ of extension, $30^{\circ}$ abduction and $20^{\circ}$ adduction Harris hip score of 85 (GOOD). 


\section{CASE REPORT}

DISCUSSION: A variety of techniques were described to reconstruct the bony deficiencies in the acetabulum, apart from fixation with bone grafts, ${ }^{3}$ like jumbo cups, ${ }^{4}$ rings, and cages. Acetabular rings.5,6,7,8 are mainly used for roof deficiencies, to prevent cup migration. On the other hand antiprotrusio cages are designed to deal with large wall and floor defects.

One such cage initially introduced by Burch and later modified by Schneider is popular among them. It prevents polyethylene cup migration. ${ }^{9,10}$ and provides medical support as well. Hence it is very appropriate to use this cage. ${ }^{11}$ in a scenario like this with large acetabular defect.

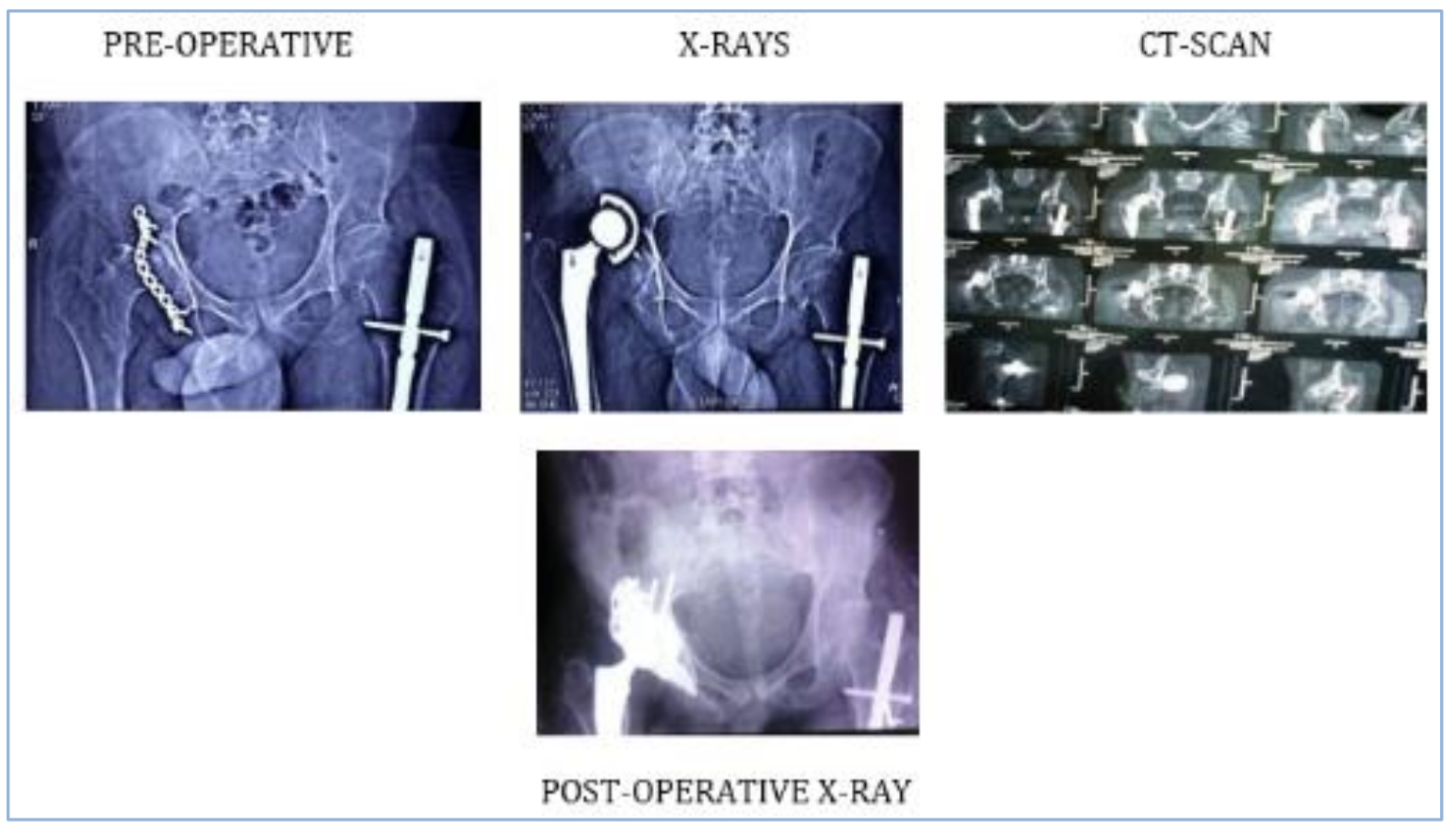

\section{REFERENCES:}

1. Paprosky WG, Perona PG, Lawrence JM. Acetabular defect classification and surgical reconstruction in revision arthroplasty: a 6-year follow-up evaluation. J Arthroplasty1994; 9: 33-44.

2. Peters CL, Curtain M, Samuelson KM. Acetabular revision with the Burch-Schnieder antiprotrusio cage and cancellous allograft bone. J Arthroplasty 1995; 10:307-12.

3. Gordon SL, Binkert BL, Rashkoff ES, et al. Assessment of bone grafts used for acetabular augmentation in total hip arthroplasty: a study using roentgenograms and bone scintigraphy. Clin Orthop 1985; 201:18-25.

4. MacKenzie JR, Callaghan JJ, Pedersen DR, Brown TD. Areas of contact and extent of gaps with implantation of oversized acetabular components in total hip arthroplasty. Clin Orthop 1994; 298:127-36.

5. Korovessis P, Spastris P, Sdougos G, et al. Acetabular roof reinforcement rings. Clin Orthop 1992; 283:149-55.

6. Mayer G, Hartseil K. Acetabular reinforcement in total hip replacement. Arch Orthop Trauma Surg 1986; 105:227-31.

7. Moretti O. The Müller reinforcement ring in surgery of the hip. Ital JOrthop Traumatol 1989; 15:177-83. 


\section{CASE REPORT}

8. Rosson J, Schatzker J. The use of reinforcement rings to reconstruct deficient acetabula. J Bone Joint Surg [Br] 1992; 74-B: 716-20.

9. Papagelopoulos PJ, Lewallen DG, Cabenela ME, McFarland EG, Wallrichs SL. Acetabular reconstruction using bipolar endoprosthesis and bone grafting in patients with severe bone deficiency. Clin Orthop 1995; 314:170-84.

10. Oakeshott RD, Morgan DF, Zukor DJ, Rudan JF, Brooks PJ. Revision total hip arthroplasty with osseous allograft reconstruction: a clinical and roentgen graphic analysis. Clin Orthop 1987; 225:37-61.

11. Jasty M, Harris WH. Results of total hip reconstruction using acetabular mesh in patients with central acetabular deficiency. Clin Orthop 1988; 237:142-9.

\section{AUTHORS:}

1. Ananthula Krishna Reddy

2. C. Kama Raj

3. Ashok Ohatker

4. Prashanth Velugu

5. B. Srinivas

\section{PARTICULARS OF CONTRIBUTORS:}

1. Assistant Professor, Department of Orthopaedics, Gandhi Medical College, Secunderabad.

2. Consultant Orthopaedic Surgeon, Department of Orthopaedics, Kamineni Hospital.

3. Professor, Department of Orthopaedics, Gandhi Medical College, Secunderabad.

FINANCIAL OR OTHER

COMPETING INTERESTS: None

4. Associate Professor, Department of Orthopaedics, Gandhi Medical College, Secunderabad.

5. Assistant Professor, Department of Orthopaedics, Gandhi Medical College, Secunderabad.

\section{NAME ADDRESS EMAIL ID OF THE CORRESPONDING AUTHOR:}

Dr. Ananthula Krishna Reddy, Bhuvana Hospital,

Ho. No. 3-13/3 Mallikarjuna Nagar, PEERZADI GUDA, Opposite Uppal Bus Depot, Hyderabad-39, Telangana.

E-mail: kr_dr@ymail.com

Date of Submission: 14/08/2015.

Date of Peer Review: 17/08/2015.

Date of Acceptance: 25/08/2015.

Date of Publishing: 03/09/2015. 